\title{
Sciendo
}

Administration, vol. 70, no. 1 (2022), pp. 97-111

doi: 10.2478/admin-2022-0008

\section{European Union, 2021}

\author{
Margaret Mary Malone \\ Institute of Public Administration, Ireland
}

Throughout the year, the EU and its member states continued to address the Covid-19 pandemic as a matter of urgency. More than a billion doses of new and efficacious vaccines, which were purchased jointly, were delivered to EU citizens while the EU exported as many more globally. The EU is the largest exporter of Covid-19 vaccines. In economic and financial terms, the EU's unprecedented pandemic recovery fund, NextGenerationEU (NGEU), was rolled out to member states, with priority given to investment projects to realise the green and digital transition of the EU economy. This marked a shift from crisis management to long-term recovery efforts. Brexit and the vexed issue of the implementation of the Northern Ireland Protocol overshadowed EU-UK relations. The simmering 'rule of law' crisis escalated as relations between the EU and the right-wing nationalist governments of Poland and Hungary deteriorated. The EU's migrant/refugee crisis entered a new phase with the advent of hybrid attacks orchestrated by the Lukashenko regime in Belarus. The climate crisis took centre stage at the twenty-sixth UN Conference of the Parties (COP26), held in Glasgow in November. In December the Merkel era drew to a close when Olaf Scholz, leader of the Social Democrats in coalition with the Liberals and the Greens, was elected Chancellor of Germany.

\section{Institutional developments}

On 1 January Portugal took up the rotating presidency of the Council of the EU with its 'trio' partners, Germany and Slovenia, in support. 
The main themes of the presidency were to deliver a successful vaccination campaign to combat Covid-19, including its variants, and to achieve economic and social recovery based on green and digital transitions.

On 1 July Slovenia followed, presiding over the Council for six months with Germany and Portugal in support. Slovenia's priorities were a timely assessment of national recovery and resilience plans under NGEU, the Conference on the Future of Europe, and assuring the rule of law and equal criteria for all, as well as enlargement, particularly in respect of the Western Balkans.

On 1 March, in the European Commission, the Taskforce for Relations with the United Kingdom came to a formal end. It was replaced by a new Service for EU-UK Agreements, which became operational on the same day.

The European People's Party (EPP), the largest political group in the European Parliament, voted overwhelmingly to change its rules to enable it to expel an entire political party with a simple majority. Previously, only individual MEPs could be ejected if found to be no longer adherent to the group's values. In 2019 the EPP voted to suspend Fidesz's membership over concerns that the rule of law was being eroded in Hungary. In a pre-emptive move, therefore, on 21 March Viktor Orban, the populist Prime Minister of Hungary and leader of the right-wing Fidesz political party, took all twelve Fidesz MEPs out of the EPP. The formal departure of Fidesz from the EPP was the culmination of growing tensions within the centre-right group. All twelve Fidesz MEPs became non-aligned or independent MEPs, losing the benefits which membership of a political group in the European Parliament confers.

In June, as part of a periodic overhaul of its strategy, the European Central Bank (ECB) announced that it would drop its 'just-below' 2 per cent inflation target in favour of a 'symmetric' target of 2 per cent, meaning that deviations in either direction were equally undesirable. This was the ECB's first strategy review since 2003. The next strategy review will be in five years' time.

\section{Post-Brexit EU-UK relations: Still negotiating}

The most prominent post-Brexit issue was the implementation of the Northern Ireland Protocol. The Protocol provides that Northern Ireland remains de facto part of the EU's customs union and in regulatory alignment with the EU's single market for goods. As a 
consequence, goods arriving from Great Britain (i.e. England, Scotland and Wales) into Northern Ireland must undergo customs checks 'down the Irish Sea'.

These customs checks quickly became a source of contention. In particular, the threatened use by the UK government of Article 16 of the Northern Ireland Protocol became a flashpoint. This article permits either side to suspend the Protocol if certain conditions are met. In early October Lord Frost, the UK's de facto Brexit Minister, indicated that the UK government wanted to renegotiate the Protocol in order to, inter alia, exclude any role for the Court of Justice of the EU (CJEU) to oversee it. The Democratic Unionist Party in Northern Ireland wanted to see the Protocol scrapped. On several occasions, the Boris Johnson government unilaterally extended the grace periods during which goods travelling from Great Britain to Northern Ireland were to be subject to customs checks. In mid March the Commission launched infringement proceedings against the UK government as negotiations continued.

The EU took the view that the UK's failure to introduce customs checks breached international law under the Withdrawal Agreement and the Northern Ireland Protocol within it. Throughout the year the Commission reiterated its position that the Northern Ireland Protocol was the only way to safeguard the Good Friday Agreement of 1998, avoid a hard border on the island of Ireland and maintain the integrity of the single European market. Having agreed the Protocol as part of an international treaty, both the UK and the EU were legally bound to implement the Protocol together in good faith.

Amid concerns that the Johnson government was making unreasonable demands regarding the Protocol, a potential EU-UK trade war loomed. On 13 October the European Commission, very much in solution mode, made a substantial offer to scrap up to 50 per cent of customs checks on British goods entering Northern Ireland, as well as removing more than half the checks on meat and plants. To mounting exasperation on the EU side, the UK government quickly responded that such concessions did not go far enough.

In mid December Lord Frost withdrew the UK demand that the role of the CJEU be removed from the Protocol. As a consequence, the UK government's threat to trigger Article 16 appeared to recede, at least for 2021. On 20 December Lord Frost resigned as Brexit Minister, citing concerns about the British government's Covid-19 policies. He was replaced by the Foreign Secretary, Liz Truss. 


\section{Ireland joins Schengen Information System}

On 15 March Ireland joined the second-generation Schengen Information System (SIS II), the largest and most widely used law enforcement database for internal security and external border management in Europe. The aim of SIS II is to support cooperation between police authorities on fighting cross-border crime and terrorism, and thus enhance EU internal security. Membership of SIS II means that An Garda Síochána may access police data and information (relating to wanted suspects, lost or stolen property) from thirty EU and Schengen countries.

Ireland is not a participant in the passport-control-free Schengen Area proper as this would mean having to end the Common Travel Area with the UK.

\section{NGEU takes effect}

On foot of approval by the European Parliament, the Recovery and Resilience Facility (RRF), the centerpiece of NGEU came into effect in late February. Member states were expected to submit their national recovery plans (NRPs) by 30 April. The Commission then assessed the plans, which the Council went on to adopt by qualified majority vote.

The RRF amounts to some $€ 723.8$ billion ( $€ 338.0$ billion in grants and $€ 385.8$ billion in loans) in current prices. The RRF accounts for 90 per cent of NGEU. The aim of the RRF is to fund public investments and structural reforms with a view to driving the twin green and digital transitions in EU member states. The core objectives of the RRF are threefold, namely:

1. help economies recover from the impact of the Covid-19 pandemic;

2. align economies with the EU's objectives in the area of climate change, and economic and social resilience;

3. implement structural reforms to achieve a level of resilience to future economic shocks.

In other words, the RRF is a short-term, post-pandemic recovery programme that focuses on long-term resilience. To this end, the RRF has six pillars: 
1. green transition;

2. digital transformation;

3. smart, sustainable and inclusive growth;

4. social and territorial cohesion;

5. health and economic, social and institutional resilience;

6. policies for the next-generation investment priorities.

All NRPs are expected to commit at least 37 per cent of funds for climate action and at least 20 per cent for digital measures. Each NRP must demonstrate how such investment and reforms will address issues and challenges identified in the context of the European Semester, particularly the country-specific recommendations adopted by the Council.

Ireland's recovery and resilience plan, which was approved by the European Commission in mid July, will be financed by $€ 989$ million in grants. Some 42 per cent of the plan's total allocation for reforms and investments will support climate objectives while some 32 per cent will support digital objectives. The recovery funds are weighted to benefit most those member states hardest hit by the pandemic, namely southern and central-eastern European countries.

\section{Health Emergency Preparedness and Response Authority}

The Commission's response to the Covid-19 pandemic was, inter alia, to announce plans for a European Health Union package. The core proposals were:

- improving the European Medicines Agency;

- upgrading the European Centre for Disease Prevention and Control;

- creating a regulation that would make ad hoc emergency measures permanent.

The most eye-catching Commission initiative was the launch of the EU's Health Emergency Preparedness and Response Authority (HERA). Commission President Ursula von der Leyen hailed HERA as a potential paradigm shift in the global fight against new variants of Covid-19. HERA involves public-private cooperation for the next phase of the virus. HERA is the EU's counterpart to the US Biomedical Advanced Research and Development Authority to mobilise resources quickly in emergencies, including investing in 
promising medical research. The Commission's proposals are limited by the EU's founding treaties, which restrict the role of the EU in health matters, even in a pandemic, to one of coordination. Public health is a competence of member states.

\section{Digital Covid Certificate}

In March the Commission proposed legislation to establish a common EU framework for the issuance, verification and acceptance of interoperable digital certificates for the purposes of non-essential travel, i.e. tourism. Three months later, on 1 July, the EU Digital Covid Certificate (DCC) Regulation entered into force. EU citizens and residents may have their DCC issued and verified across the EU. The DCC was deemed essential to safeguard the free movement of people, a core EU citizenship right, during the Covid-19 pandemic. Originally the idea of the Greek Prime Minister and supported by other tourism-reliant countries, the aim of the DCC was to facilitate the safe return of cross-border tourism and, inter alia, help revive the hard-hit aviation industry. By year's end, more than 800 million certificates had been issued in the EU. Some sixty countries and territories across five continents have joined the system.

The DCC provides standardised recognition of the holder's:

- proof of vaccination; or

- results of a negative PCR (polymerase chain reaction) test; or

- information on recovery from Covid-19.

Each member state continues to determine its own entry requirements and rules, which are not standardised at EU level. In other words, national authorities may still impose restrictions if deemed necessary.

The DCC, which is issued by national authorities free of charge, is available in digital and paper format. It has a QR (Quick Response) code to ensure the security and authenticity of the certificate, which can be stored on a smart phone. The EU gateway allowed for verification of digital signatures contained in the QR codes of all certificates without the processing of personal data. The DCC went live at EU level on 1 June with seven vanguard member states introducing it, namely Bulgaria, Czechia, Denmark, Germany, Greece, Croatia and Poland. It was officially available from 1 July in all member states save Ireland, which joined the system on 19 July, the delay being prompted by a cyberattack experienced by the Health Service Executive. 
On 29 October Armenia and the UK joined the EU system, meaning that the QR codes issued by them were recognised as equivalent to the DCC.

On 21 December the EU agreed to extend the validity of the DCC to nine months (270 days to be precise) to fully vaccinated EU citizens. Member states may impose further requirements on travellers (e.g. negative PCR test, quarantine) so long as they are proportionate. The extension was scheduled to come into effect from 1 February 2022.

\section{2}

On 11 February the common EU number for emergency communications, 112, marked its thirtieth anniversary. In 2019 Europeans called 112 almost 150 million times, accounting for some 56 per cent of all emergency calls. In the last ten years, some 1.5 billion calls were made to the number.

\section{Conference on the Future of Europe}

The first initiative of this kind, the Conference on the Future of Europe is a multilingual digital platform, offering EU citizens an opportunity to shape how the EU will look in the near future. Launched on 9 May, Schuman Day, at the European Parliament in Strasbourg, thousands of citizens' discussion groups began to take place across the Union. The conference is expected to reach conclusions by Spring 2022.

The topics cover nine areas, ranging from climate change and the environment to health, social justice and jobs, EU in the world, values and rights, digital transformation, European democracy and migration.

\section{Belarus wages a hybrid war with the $\mathrm{EU}$}

On 24 May the European Council agreed unanimously to impose targeted sanctions against the regime of the autocratic leader of Belarus, Alexander Lukashenko, and to sever aviation links with that country. This was a quick and forceful response to an incident on 23 May when Belarus scrambled a warplane to intercept a Ryanair aircraft flying from Athens to Vilnius which had briefly entered Belarusian airspace. Belarusian authorities claimed, falsely, that an explosive device was onboard. The flight was forcibly diverted to 
Minsk. Once on Belarusian soil, the prominent dissident journalist and political activist Roman Protasevich and his partner were immediately arrested and detained. Protasevich is an outspoken opponent of Lukashenko.

Opposition to Lukashenko's rule in Belarus is reputedly huge and growing, with many Belarusians demanding new, democratic political leadership and economic reform.

The EU imposed sanctions on Lukashenko and his allies in 2020 in response to the brutal crackdown of pro-democracy protests which took place following his discredited presidential election victory in August of that year.

In retaliation against the EU for tightening sanctions, Belarusian authorities subsequently welcomed planeloads of 'tourists' from, among other places, Iraq (mostly Kurds), Syria and African states such as the Democratic Republic of Congo, who were then directed to cross the border illegally into Lithuania, Latvia and Poland to seek asylum in the EU as refugees. The EU thus faced a new phase in its migrant crisis as the Belarusian authorities, in effect, sought to weaponise migrants, waging a hybrid war with the EU. The number of refugees and would-be migrants arriving into the EU rose sharply to several thousand within a matter of weeks. In November, following a new influx of migrants, Polish ministers accused Vladimir Putin, President of Russia and a supporter of Lukashenko, of masterminding the human wave in order to destabilise the EU. In early November Russia dispatched two nuclear-capable strategic bombers to patrol Belarusian airspace.

In mid November the EU approved a new (fifth) set of targeted sanctions against the Lukashenko regime. The EU also extended its sanctions list for human trafficking and smuggling to include airlines facilitating the transition of illegal migrants. This proved effective in reducing the influx. Meanwhile, a humanitarian crisis loomed as desperate migrants stranded at the Polish-Belarus border were left without regular access to food, water or shelter as temperatures dropped to freezing. Tensions eased somewhat when Belarusian authorities backed down and organised repatriation flights.

Meanwhile, approximately 100,000 Russian troops were observed massing on the Russian-Ukrainian border. Amid growing concern regarding Putin's seemingly belligerent intentions, a G7 meeting in December issued a warning of serious consequences should Russia invade Ukraine. 


\section{European Public Prosecutor's Office begins work}

On 1 June the European Public Prosecutor's Office (EPPO) officially began work. EPPO is an independent office established to tackle corruption and misuse of EU funds, the bulk of which is disbursed by member states. Its director is Laura Codruta Kovesi, the former chief prosecutor of Romania's National Anticorruption Directorate. For the first time, EU budget fraud may be investigated and prosecuted at EU level. EPPO's launch was overshadowed by Slovenian authorities delaying the appointment of delegated prosecutors in its country. As EPPO requires national prosecutors equipped with local knowledge and linguistic skills to fulfil its mandate, this delay hampered somewhat the work of the new office.

Denmark, Ireland, Hungary, Poland, Sweden have not signed up to EPPO, which was established using the Enhanced Cooperation mechanism for which Article 20 Treaty on the European Union (TEU) provides. Enhanced Cooperation permits a minimum of nine member states to use the procedures and institutions of the EU to introduce new areas of European integration. EPPO joins the EU's so-called Justice League, which includes the CJEU, Eurojust, Europol and OLAF, to protect the Multi-annual Financial Framework (MFF) for 2021 to 2027 and NGEU.

\section{EU relations with the Biden administration}

On 15 June US President Joe Biden visited Brussels to meet with members of the European Council. Signalling a move towards a more cooperative relationship after difficult relations with the Trump administration, Biden envisioned pan-Western solidarity against the weight of China, an emerging economic and political giant in the world and a potential threat to both the US and the EU. The visit was intended to demonstrate Biden's strong commitment to the transatlantic relationship, NATO, the G7, the EU and multilateralism in general. Biden's agenda focused on the 'three Cs': Covid, climate and China.

Launching a new Trade and Technology Council, the EU-US summit announced a series of joint actions on Covid-19, climate change, trade, investment, technology, defending human rights and democracy, as well as more joint work and cooperation in the area of security and defence. A breakthrough was declared on a seventeenyear-old trade dispute on subsidies paid to the US company Airbus 
and its European rival, Boeing. It was agreed to suspend billions of euro and US dollars' worth of tit-for-tat tariffs as both the EU and the US committed to removing unfair subsidies. The suspension is to be reviewed in five years' time.

On 27 July President Biden nominated former US Ambassador Mark Gitenstein as the US Ambassador to the EU. Ambassador Gitenstein is of Romanian Jewish descent and had spent seventeen years in the US Senate.

The precipitous US withdrawal from Afghanistan on 26 August and the subsequent chaotic evacuation effort which followed unsettled EU-US relations. The unexpected announcement of AUKUS, a trilateral security pact between Australia, the UK and the US, on 15 September further overshadowed the revitalised EU-US relationship. Josep Borrell, the EU's foreign policy chief, called for the EU to develop its own military capacity independent of the US, to include a deployable expeditionary joint military reaction force, 50,000 personnel strong. The notion of 'EU strategic autonomy' became current.

\section{EU-China relations}

The EU-China Comprehensive Agreement on Investment, concluded in principle on 30 December 2020, saw no progress during 2021. European public opinion and the EU political establishment turned when Chinese authorities imposed sanctions on selected MEPs, think tanks and academics. The sanctions were in response to restrictive EU measures against two individuals and one entity deemed responsible for mass human rights violations in Xinjiang, affecting the Uyghur community in particular. Chinese authorities reject Western allegations of human rights abuses in the predominantly Muslim region.

\section{Rule of law crisis escalates: Towards Polexit?}

Widespread concern about habitual rule-of-law violations in Poland escalated throughout the year. On 31 March the Commission referred Poland to the CJEU in a move to protect the independence of the Polish judiciary. On 21 July the CJEU ordered the Law \& Justice (PiS) government to suspend its recently created 'Disciplinary Chamber' for judges. The CJEU ruled that the law establishing this disciplinary 
mechanism - which, inter alia, lifted the immunity of judges, potentially exposing them to arbitrary criminal charges - interfered with the independence of the Polish judiciary and was not compatible with EU law. On 7 October the Polish Constitutional Court - its own legitimacy and political independence very much in doubt - in a bombshell ruling declared that Poland's constitution took precedence over EU treaties. In short, the primacy of EU law over national law was no longer unconditional in Poland. This challenge by the partisan court to the primacy principle, a fundamental pillar of the EU's legal order, was immediately decried by Polish opposition leaders, including Donald Tusk, former President of the European Council (2014-19), who saw the move as the latest indication of the politicisation of the judiciary by the PiS party, in power in Poland since 2015. Mass public protests ensued as Poles feared a slippery slope to Poland's exit from the EU, or 'Polexit'.

On 27 October the CJEU imposed a record fine of $€ 1$ million daily on Poland for non-compliance with its ruling of 21 July to disband its Disciplinary Chamber for judges. The fine was to ensure that the PiS government took action to protect the legal order of the EU and the values on which it is founded, in particular the rule of law. In a followup, von der Leyen, on 28 October, set out a road map to de-escalate tensions between the EU and the PiS government and thereby unlock the first tranche of Covid-19 recovery funds earmarked for Poland. The PiS government had to: (1) dismantle the 'Disciplinary Chamber' ruled illegal by the CJEU on 21 July; (2) end or reform the new disciplinary regime; and (3) re-install judges either sacked or forced into early retirement. Reform, von der Leyen emphasised, was 'conditio sine qua non' (an indispensable condition). Poland's National Recovery and Resilience Plan was not signed off as the dispute continued, meaning NGEU funds earmarked for Poland did not flow.

In a similar vein, on 23 June, the Commission opened legal proceedings against Hungary, citing the need to guarantee freedom of expression as grounds for action. Hungary's law banning the 'portrayal or promotion' of LGBTQI+ identity to minors is seen as contrary to Article 2 of the TEU, which defines the core values of the EU. The law, introduced by the ruling right-wing nationalist Fidesz party, was criticised by some within the EU as discrimination against minorities.

The EU is also concerned by Fidesz government measures which undermine media pluralism and court independence. 


\section{CAP reform delivered}

On 28 June, after three years of intense negotiations, a new package of reforms for the new Common Agricultural Policy (CAP) was finally agreed. The package represents a shift towards a greener, fairer and more performance-based CAP to provide a more sustainable future for European farmers. The aim of negotiations was to achieve a balance between economic development of farms on the one hand and the necessary protection of the environment, including climate mitigation measures, on the other. The agreement includes new measures to ensure more targeted support for smaller farms. For example, to help young farmers to enter the profession, member states are required to redistribute at least 10 per cent of CAP funds to smaller farms. Approximately one-third of the EU's long-term budget, the MFF for the period 2021-7, will be spent on payments to farmers and support for regional development. To curb agriculture's environmental impact, the new reform requires member states to spend 20 per cent of payments to farmers from 2023 to 2024, rising to 25 per cent in 2025-7, on 'eco-schemes'. This may include, for example, schemes to restore wetlands to absorb $\mathrm{CO}_{2}$ or to promote organic farming. The new rules apply from 2023.

\section{'Fit for 55' climate action package}

On 14 July the Commission unveiled its landmark legislative package of energy and climate action to pivot EU economies away from fossilbased fuels towards a new, more sustainable model. The thirteen legislative proposals - some new, while others are revisions of existing laws - cover everything from the use of land and forestry to the EU's Emissions Trading System (ETS), to changes to carbon pricing, including imports as well as new $\mathrm{CO}_{2}$ emission reduction targets for the car industry. The ambitious 'Fit for 55' package is a root-andbranch review of the EU's energy and climate laws. It aims to realize the von der Leyen Commission's headline goal to make Europe the first climate-neutral continent in the world by reducing greenhouse gases by 55 per cent by 2030 compared to 1990 levels.

Integral to this comprehensive package is the notion of carbon pricing - that is, tightening the number of permits issued to shipping and aviation industries, for example. The most controversial part of the whole package, according to First Executive Vice-President of the Commission Frans Timmermans, who has responsibility for the 
European Green Deal, is the proposal for a second ETS covering fuels used for road transport and for heating buildings.

\section{EU-Western Balkans Summit - Don't mention the 'E' word}

On 6 October Slovenia hosted an EU-Western Balkans Summit. A number of announcements were agreed at the summit, including:

- $\mathrm{a} € 30$ billion investment programme;

- a commitment to achieve the same level of Covid-19 vaccination by the end of 2021 in the six Western Balkan states as in the EU;

- plans to phase out mobile roaming charges between the region and the EU.

There was, however, no update on visa liberalisation, a key issue for the EU candidate hopefuls, and no key dates or timetable for accession negotiations. In sum, the summit did not live up to expectations in an atmosphere of apparent enlargement fatigue among member states. Member states continue to discuss the capacity of the EU to take on new members. Von der Leyen warned that any undue delay could jeopardise the EU's standing in the region, where both China and Russia have an interest.

To date, accession negotiations with Serbia and Montenegro are proceeding at a snail's pace, Albania and North Macedonia have been given the green light by Council but negotiations have yet to begin, while Bosnia and Herzegovina has yet to be given the nod for membership.

\section{OECD and a global corporate tax rate}

In October the OECD agreed a landmark tax deal on corporate tax reform. Pillar 1 will oblige businesses to pay more tax where they operate. Pillar 2 sets a new global minimum corporate tax rate of 15 per cent for businesses with revenue exceeding $€ 750$ million per annum. Von der Leyen welcomed the move as a major step towards a fairer global tax system. The Commission also called for parallel efforts to crack down on tax avoidance and evasion to continue. At the end of October the G20, where the EU is represented, finalised the details, with implementation to follow. The new rules are due to come into effect in 2023, subject to the adoption of enabling legislation in all participating countries. 
The OECD comprises thirty-eight full member countries from North and South America to Europe and Asia-Pacific. The OECD and its key partners represent some 80 per cent of world trade and investment.

\section{Climate action and COP26}

At COP26 the US and the EU gathered with more than a hundred countries to agree pledges to convert aspiration into action on the climate crisis. If implemented in full, such agreements could keep the world's rising temperature to within 1.8 degrees of pre-industrialised levels, according to the International Energy Agency. In particular, a landmark pledge was made to slash emissions of the powerful greenhouse gas methane - the second-largest contributor to climate change after $\mathrm{CO}_{2}$ - by 30 per cent below 2020 levels by 2030. If met, this could prevent 0.2 degrees of warming by the mid-twenty-first century. Notable absentees from COP26 were the leaders of China and Russia. The Swedish teenage climate activist Greta Thunberg, cofounder of the global Fridays for Future movement, dismissed the two-week conference as 'a PR exercise'.

\section{Post-Merkel era begins}

In September federal elections in Germany saw the effective end of Angela Merkel's tenure as Chancellor. Having served as Chancellor for four consecutive terms since 2005, Merkel became the longestserving head of government in the EU. Noted for her pragmatic approach to crisis management, mild manner, cool gravitas and legendary endurance at marathon European Council negotiations, Merkel was Europe's most experienced and influential politician, playing a key role in EU affairs from the euro area crisis of 2008 to the present-day Covid-19 pandemic. The September elections saw a narrow victory for the Social Democrats Party, led by Olaf Scholz, a historic low for the Christian Democratic Union and their sister party, the Christian Socialists Union, a notable drop in support for the anti-immigration party, Alternative für Deutschland, and a strong showing for the Greens and the Liberals. Though a number of coalition constellations were theoretically possible, the so-called 'ampel-koalition' ('traffic-light coalition') of the Socialist Democratic Party (red), the pro-business Liberal party (yellow or amber) and the Greens was an early favourite to form the new government. In late 
November the three parties successfully concluded coalition negotiations with a strong pro-EU programme at its core. In early December Scholz, who served as Merkel's finance minister and vice chancellor since 2018, duly took office as the new Chancellor of Germany.

\section{Sakharov Prize for Freedom of Thought 2021}

During its December plenary, the European Parliament awarded its Sakharov Prize for Freedom of Thought to prominent Russian opposition politician and anti-corruption activist Alexei Navalny. The prestigious prize was accepted on behalf of the imprisoned Navalny by his daughter, Daria. 